\title{
First record of Proprioseiopsis citri (Muma) (Acari: Phytoseiidae) from Brazil with a complementary description
}

Jandir C. Santos, Gilberto J. de Moraes \& Peterson R. Demite

To cite this article: Jandir C. Santos, Gilberto J. de Moraes \& Peterson R. Demite (2017) First record of Proprioseiopsis citri (Muma) (Acari: Phytoseiidae) from Brazil with a complementary description, International Journal of Acarology, 43:2, 165-168, DOI: 10.1080/01647954.2016.1267260

To link to this article: https://doi.org/10.1080/01647954.2016.1267260

曲 Published online: 14 Dec 2016.

Submit your article to this journal ¿

Џ Article views: 79

View Crossmark data \lceil 


\title{
First record of Proprioseiopsis citri (Muma) (Acari: Phytoseiidae) from Brazil with a complementary description
}

\author{
Jandir C. Santos ${ }^{a}$, Gilberto J. de Moraes ${ }^{b}$ and Peterson R. Demite (i) ${ }^{c}$ \\ aDepartamento de Fitossanidade, FCAV-UNESP, Jaboticabal, Brazil; 'bepartamento de Entomologia e Acarologia, ESALQ-Universidade de São \\ Paulo, Piracicaba, Brazil; 'Instituto Federal Goiano, Campus Urutaí, Urutaí, Brazil
}

\section{ABSTRACT}

Proprioseiopsis citri (Muma) (Acari: Phytoseiidae) is reported for the first time from Brazil. The specimens were collected from litter in Jaboticabal, State of São Paulo, Brazil. Measurements of holotype also are provided and the male is described for first time. A key to the species of Proprioseiopsis from Brazil is provided.

\section{ARTICLE HISTORY}

Received 10 October 2016

Accepted 27 November

2016

Published online 14

December 2016

\section{KEYWORDS}

Amblyseiinae; diversity; litter; Proprioseiopsina; taxonomy
The Phytoseiidae Berlese (Acari: Mesostigmata) is a highly diverse predatory mite family with more than 2700 species described (Demite et al. 2014, 2016). Phytoseiid mites are recognized as effective natural enemies against certain agricultural arthropod pests (Gerson et al. 2003; McMurtry et al. 2013, 2015), increasing its importance as one of the best-studied mite families.

Proprioseiopsis Muma is the sixth largest genus in the family Phytoseiidae containing 164 described species (Demite et al. 2016). In Brazil, 10 described species have been recorded (see Phytoseiidae Database: Demite et al. 2016).

The objective of this article is to provide a complementary description complementary of Proprioseiopsis citri, based on an examination of the holotype and of additional specimens collected in Brazil, where it is reported for the first time. A key to Proprioseiopsis in Brazil is provided.

\section{Materials and methods}

Mites were mounted on slides with Hoyer's medium and examined under a phase-contrast microscope. Illustrations were made using a drawing tube. Dorsal and ventral setal nomenclature is that of Rowell et al. (1978) and Chant and Yoshida-Shaul (1991) respectively. All measurements are given in micrometres indicating measurements of the holotype in brackets followed by mean for the Brazilian specimens measured, and (in parentheses) by the respective range. The Brazilian specimens are deposited in the mite reference collection of Departamento de Entomologia e Acarologia, Escola Superior de Agricultura "Luiz de Queiroz", Universidade de São Paulo, Piracicaba, São Paulo State, Brazil.

\section{Results and discussion}

Proprioseiopsis citri (Muma, 1962)

(Figures. 1-7)

Amblyseiulus citri Muma 1962: 1, 1964: 11, 1968: 41.

Typhlodromus citri - Hirschmann 1962: 6.

Proprioseiopsis citri - Denmark \& Muma 1970: 221; Muma \& Denmark 1970: 36; Muma 1975: 56; Moraes et al. 1986: 113, 2004: 174; Karg 1989: 202; Farrier \& Hannessey 1993: 123; Chant \& McMurtry 2005: 15, 2007: 89; Denmark \& Evans 2011: 197; Demite et al. 2016.

\section{Specimens examined}

Holotype: female collected from litter at Sebring, Florida, USA, collected by M.H. Muma, 18-VII-1960; Brazilian specimens: 7 females and 1 male collected from litter at base of Bougainvillea spectabilis Willd (Nyctaginaceae), Jaboticabal $\left(21^{\circ} 14^{\prime} 44^{\prime \prime} \mathrm{S}\right.$; $\left.48^{\circ} 17^{\prime} 15^{\prime \prime} \mathrm{W}\right)$, São Paulo State, Brazil, collected by J.C. Santos, 10-VII-2012.

\section{FEMALE}

(Holotype +7 Brazilian specimens)

Dorsum (Figure 1). Dorsal shield mostly smooth, with a few anterolateral striae, [331] 319 (313-328) long and [220] 227 (220-238) wide; j1 [26] 25 (21-27), j3 [39] 39 (38-41), j4 [5] 5 (56), j5 [5] 5 (5-6), j6 [5] 6, J5 [12] 7 (6-8), z2 [17] 17 (16-19), z4 [9] 12 (10-13), z5 [5] 5 (5-6), Z1 [7] 8 (7-10), Z4 [88] 82 (80-85), Z5 [79] 78 (76-85), s4 [70] 70 (67-72), S2 [13] 10 (10-12), S4 [10] 9 (810), S5 [11] 10 (9-10), r3 [25] 25 (23-27), R1 [13] 15 (15-16). All dorsal setae smooth.

Peritreme. Extending forward to level of $j 1$.

Venter (Figure 2). Sternal and genital shields smooth, distances between st1-st3 [61] 60 (59-61), st2-st2 [68] 72 (70-75) and st5-st5 [68] 70 (63-73); ventrianal shield pentagonal, striated anteriorly and smooth posteriorly, with three pairs of pre anal setae (JV1, $J V 2$ and $Z V 2) ;$ [109] 110 (101-117) long, [106] 105 (102-109) wide at level of $Z V 2$ and [94] 94 (91-97) wide at level of anus; four pairs of opisthogastric setae on unsclerotized cuticle (JV4, JV5, ZV1 and ZV3); JV5 [78] 73 (71-77). All ventral setae smooth. Two pairs of metapodal plates present.

Chelicera (Figure 3). Movable cheliceral digit [24] 25 (24-26) long, with 2 teeth; fixed digit [27] 26 (25-27) long, with 7-8 teeth.

Spermatheca (Figure 4). Calyx trumpet-shape, [25] 24 (22-27) long; atrium swollen.

Legs (Figure 5). Sgelll [25] 24 (23-25), Stilll 29, SgelV [64] 59 (5964), StilV [47] 43 (40-46), StIV [55] 58 (56-59); all macrosetae sharp-tipped. Chaetotaxy: genu II 2-2/0-2/0-1; genu III 1-2/1-2/ $0-1$. 

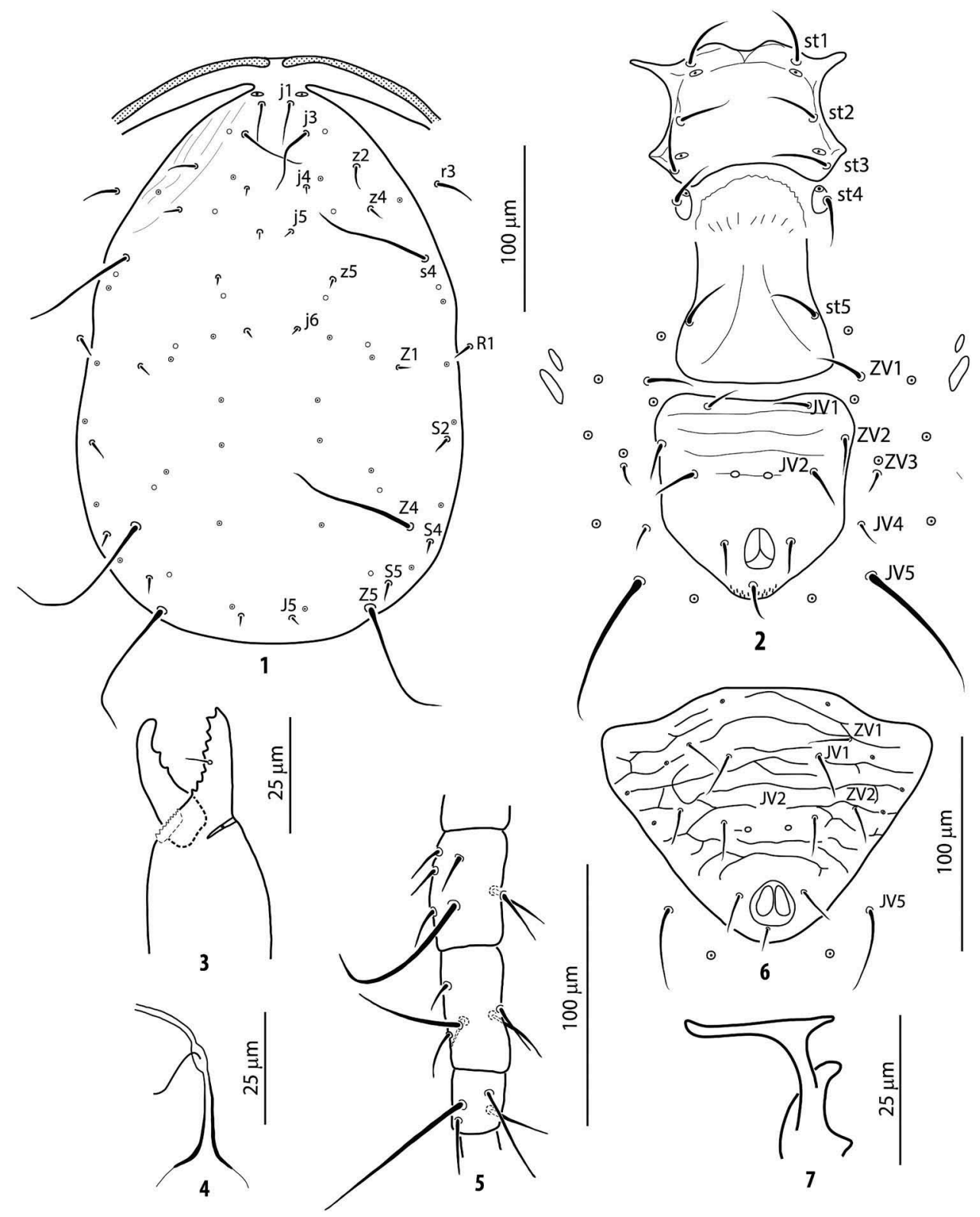

Figures 1-7. Proprioseiopsis citri (Muma). Female: 1. Dorsal shield; 2. Ventral idiosoma; 3. Chelicera; 4. Spermatheca; 5. Genu, tibia and basitarsus of leg IV. Male: 6. Ventrianal shield; 7. Spermatodactyl.

\section{MALE}

(1 Brazilian specimen)

Dorsum. Dorsal shield mostly smooth, with a few anterolateral striae, 263 long and 190 wide; $j 118, j 330, j 46, j 56, j 65, J 58, z 2$ $14, z 410, z 56, Z 112, Z 471, Z 550, s 447, S 210, S 410, S 510, r 318$, $R 18$. All dorsal setae smooth.

Peritreme. Extending to level of $j 1$.

Venter (Figure 6). Sternogenital and ventrianal shields reticulate ventrianal shield subtriangular; 115 long and 143 wide at anterior corners, with four pairs of pre-anal setae, one pair of pores mediad bases of JV2, and four pairs of lyrifissures; JV5 35.

\section{Spermatodactyl (Figure 7). Shaft 20 long.}

Legs. Macrosetae sharp-tipped, lengths: SgelV 43, StilV 27, StIV 45. Chaetotactic formulae of genua II and II as in females.

\section{Previous records}

Paraguay [Denmark \& Muma (1970)] and USA [Alabama: Fadamiro et al. (2009); Florida: Muma $(1962,1964,1968)$, Muma \& Denmark (1970), Denmark \& Evans (2011)].

\section{Remarks}

Until now, P. citri was reported only from USA (Alabama and Florida) and from Paraguay. In both countries, it was found in litter, the same substrate onto which it was found in the present study; it was also reported once from citrus bark (Denmark and Muma 1970). Fadamiro et al. (2009) did not mention in which substrate [citrus leaves/fruits or ground cover plants (weeds)] this species was recorded. The original description of $P$. citri was brief, with measurements only of the dorsal shield of female and male adults. Measurements of setae of a single specimen, probably from Florida, were reported by Schicha (1980). Measurements of the present study are similar to those provided in that paper, except for macrosetae of genu and tibia IV, about 30\% longer in the holotype and in the Brazilian specimens. 


\section{Key for species of Proprioseiopsis from Brazil}

1. Genu I with a macroseta..... peruvianus species group Chant

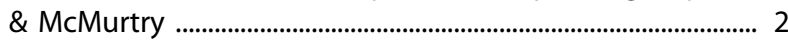

1'. Genu I without macroseta ..... belizensis species group Chant \& McMurtry

2 (1). Calyx of spermatheca saccular, elongate, constricted near the middle and flared near the base. Proprioseiopsis jasmini (El-Banhawy)

2'. Calyx of spermatheca saccular, bell-shaped, without any constrictions

$3\left(2^{\prime}\right)$. Seta $j 1$ at least $25 \mu \mathrm{m}$; setae $Z 4$ and $Z 5$ at most 130 and 132 $\mu \mathrm{m}$, respectively.

Proprioseiopsis biologicus Lofego, Demite \& Moraes

3'. Seta $j 117 \mu \mathrm{m}$; setae $Z 4$ and $Z 5$ at least 140 and $152 \mu \mathrm{m}$, respectively

.... Proprioseiopsis pariquerassuensis Moraes, Barbosa \& Castro

4. (1') Calyx of spermatheca short, cup-shaped .......asetus species subgroup Chant \& McMurtry............Proprioseiopsis mexicanus (Garman) (= P. asetus: according Denmark \& Evans 2011)

4'. Calyx of spermatheca longer, not cup-shaped 5

$5\left(4^{\prime}\right)$. Calyx of spermatheca bell-shaped or saccular belizensis species subgroup Chant \& McMurtry

5'. Calyx elongate, tubular......................pascuus species subgroup Chant \& McMurtry

6 (5). Seta $j 3$ at most $20 \%$ longer $(<45 \mu \mathrm{m})$ than the distance between its base and that of seta $z 2$.

Proprioseiopsis neotropicus Ehara

6 . Seta $j 3$, at least $50 \%$ longer $(>65 \mu \mathrm{m})$ than the distance between its base and that of seta $z 2$.

7 (6') Seta $z 2$ shorter than $z 4$..

Proprioseiopsis dominigos (El-Banhawy)

7'. Seta $z 2$ longer than $z 4$.......................................Proprioseiopsis ovatus (Garman) (= P. cannaensis: according Denmark \& Evans 2011)

8 (5') Seta $Z 4$ markedly shorter than Z5; calyx of spermatheca at least $45 \mu \mathrm{m}$

Proprioseiopsis pentagonalis Moraes \& Mesa

8'. Seta Z4 slightly longer than Z5; calyx of spermatheca about $25 \mu \mathrm{m}$ Proprioseiopsis citri (Muma)

\section{Acknowledgments}

To Ronald Ochoa (USDA-USA) by loaning the holotype of Proprioseiopsis citri. Jandir C. Santos receives scholarship of Coordenação de Aperfeiçoamento de Pessoal de Nível Superior (CAPES); Gilberto J. Moraes receives a researcher fellowship from CNPq [Proc. 304930/2014-8] and Peterson R. Demite receives financial support provided by CNPq/FAPEG within the " Desenvolvimento Científico e Tecnológico Regional (DCR)" Program [Proc. no. 303016/2014-0].

\section{Funding}

This work was supported by the Coordenação de Aperfeiçoamento de Pessoal de Nível Superior (CAPES); CNPq [Proc. 304930/2014-8]; CNPq/FAPEG within the "Desenvolvimento Científico e Tecnológico Regional (DCR)" Program [Proc. 303016/2014-0].

\section{ORCID}

Peterson R. Demite (D) http://orcid.org/0000-0001-6376-5463

\section{References}

Chant DA, McMurtry JA. 2005. A review of the subfamily Amblyseiinae Muma (Acari: Phytoseiidae): part V. Tribe Amblyseini, subtribe Proprioseiopsina Chant \& McMurtry. International Journal of Acarology 31:3-22.

Chant DA, McMurtry JA. 2007. Illustrated keys and diagnoses for the genera and subgenera of the Phytoseiidae of the world (Acari: Mesostigmata). West Bloomfield (MI): Indira Publishing House.

Chant DA, Yoshida-Shaul E. 1991. Adult ventral setal patterns in the family Phytoseiidae (Acari: Gamasina). International Journal of Acarology 17:187-199.

Demite PR, McMurtry JA, Moraes GJ. 2014. Phytoseiidae database: a website for taxonomic and distributional information on phytoseiid mites (Acari). Zootaxa 3795:571-577.

Demite PR, Moraes GJ, McMurtry JA, Denmark HA, Castilho RDC. 2016. Phytoseiidae database [Internet]. Piracicaba: Escola Superior de Agricultura "Luiz de Queiroz" - Universidade de São Paulo. Available from: http://www.lea.esalq.usp.br/ phytoseiidae

Denmark HA, Evans GA. 2011. Phytoseiidae of North America and Hawaii (Acari: Mesostigmata). West Bloomfield (MI): Indira Publishing House.

Denmark HA, Muma MH. 1970. Some phytoseiid mites of Paraguay (Phytoseiidae: Acarina). The Florida Entomologist 53:219-227.

Fadamiro HY, Xiao Y, Nesbitt M, Childers CC. 2009. Diversity and seasonal abundance of predacious mites in Alabama Satsuma Citrus. Annals of the Entomological of Society of America 102:617-628.

Farrier MH, Hennessey MK. 1993. Soil-inhabiting and free-living Mesostigmata (Acari-Parasitiformes) from North America. An Annotated checklist with bibliography and index. North Caroline Agriculture Research Service Technical Bulletin 302:1-408.

Gerson U, Smiley RL, Ochoa R. 2003. Mites for pest control. Oxford: Blackwell Science.

Hirschmann W. 1962. Gangystematik der Parasitiformes. Acarologie Schriftenreihe fur Vergleichende Milbenkunde Hirschmann-Verlag, Furth/Bay. 5:80 pp.+ 32 plates.

Karg W. 1989. Neue Raubmilbenarten der Gattuig Proprioseiopsis Muma, 1961 (Acarina, Parasitiformes) mit Bestimmungsschlusseln. Zoologische Jahrbucher Systematik 116:199-216.

McMurtry JA, Moraes GJ, Famah Sourassou N. 2013. Revision of the lifestyles of phytoseiid mites (Acari: Phytoseiidae) and implications for biological control strategies. Systematic and Applied Acarology 18:297-320.

McMurtry JA, Famah Sourassou N, Demite PR. 2015. The Phytoseiidae (Acari: Mesostigmata) as biological control agentes. In: Carrilo D, Moraes GJ, Peña JE, editors. Prospects for biological control of plant feeding mites and other harmful organisms. Cham $(\mathrm{CH})$ : Springer International Publishing; $\mathrm{p}$. 133-149. doi:10.1007/978-3-319-15042-0_5

Moraes GJ, McMurtry JA, Denmark HA. 1986. A catalog of the mite family Phytoseiidae. References to taxonomy, synonymy, distribution and habitat. Brasília: EMBRAPA-DDT.

Moraes GJ, McMurtry JA, Denmark HA, Campos CB. 2004. A revised catalog of the mite family Phytoseiidae. Zootaxa 434:1-494.

Muma MH. 1962. New Phytoseiidae (Acarina: Mesostigmata) from Florida. The Florida Entomologist 45:1-10.

Muma MH. 1964. Annotated list and keys to Phytoseiidae (Acarina: Mesostigmata) associated with Florida citrus. University of Florida Agricultrual Experiment Station Bulletin 685:1-42. 
Muma MH. 1968. Phytoseiidae of sand-pine litter. The Florida Entomologist 51:37-44.

Muma MH. 1975. Mites associated with citrus in Florida. University of Florida Agricultural Experiment Station Bulletin 640A:1-92pp.

Muma MH, Denmark HA. 1970. Phytoseiidae of Florida. In Arthropods of Florida and neighboring land areas. Vol. 6. Gainesville (USA): Florida Department of Agriculture and Consumer Services, Division of Plant Industry; p. 150pp.
Rowell HJ, Chant DA, Hansell RIC. 1978. The determination of setal homologies and setal patterns on the dorsal shield in the family Phytoseiidae (Acarina: Mesostigmata). The Canadian Entomologist 110:859-876.

Schicha E. 1980. Three new species (Acari: Phtyoseiidae) from Australia and collection records of two first described from Madagascar and Hawaii. International Journal of Acarology 6:245-253. 